\title{
Eight glacial cycles from an Antarctic ice core
}

EPICA community members*

${ }^{*} A$ full list of authors appears at the end of the paper

The Antarctic Vostok ice core provided compelling evidence of the nature of climate, and of climate feedbacks, over the past 420,000 years. Marine records suggest that the amplitude of climate variability was smaller before that time, but such records are often poorly resolved. Moreover, it is not possible to infer the abundance of greenhouse gases in the atmosphere from marine records. Here we report the recovery of a deep ice core from Dome C, Antarctica, that provides a climate record for the past 740,000 years. For the four most recent glacial cycles, the data agree well with the record from Vostok. The earlier period, between 740,000 and 430,000 years ago, was characterized by less pronounced warmth in interglacial periods in Antarctica, but a higher proportion of each cycle was spent in the warm mode. The transition from glacial to interglacial conditions about 430,000 years ago (Termination V) resembles the transition into the present interglacial period in terms of the magnitude of change in temperatures and greenhouse gases, but there are significant differences in the patterns of change. The interglacial stage following Termination V was exceptionally long-28,000 years compared to, for example, the 12,000 years recorded so far in the present interglacial period. Given the similarities between this earlier warm period and today, our results may imply that without human intervention, a climate similar to the present one would extend well into the future.

The climate of the last 500,000 years ( $500 \mathrm{kyr}$ ) was characterized by extremely strong 100-kyr cyclicity, as seen particularly in ice-core ${ }^{1}$ and marine-sediment ${ }^{2,3}$ records. During the earlier part of the Quaternary (before 1 million years ago; $1 \mathrm{Myr} \mathrm{BP}$ ), cycles of $41 \mathrm{kyr}$ dominated. The period in between shows intermediate behaviour, with marine records showing both frequencies and a lower amplitude of the climate signal ${ }^{2,3}$. The observed frequencies arise from parameters of the Earth's orbit that control the amount, and the seasonal and latitudinal distribution, of solar radiation ${ }^{4}$. However, the reasons for the dominance of the 100-kyr (eccentricity) over the 41-kyr (obliquity) band in the later part of the record, and the amplifiers that allow small changes in radiation to cause large changes in global climate, are not well understood. New records of the earlier periods, looking at parameters unavailable in marine records, are needed.

Ice cores provide the most direct and highly resolved records of (especially) atmospheric parameters over these timescales. They record climate signals, as well as forcing factors of global significance such as greenhouse gases and of more regional significance such as atmospheric aerosol content. Until now, ice-core data have been available only for the past $420 \mathrm{kyr}$, with the longest record coming from Vostok in East Antarctica ${ }^{1}$, supported by the 340-kyr record from Dome Fuji ${ }^{5}$. These data indicated the similarities of the last four glacial terminations. They showed that glacials and interglacials had similar bounds in the measured properties over the last four cycles. Most tellingly, they showed the very close association between greenhouse gases ${ }^{1,6}\left(\mathrm{CO}_{2}, \mathrm{CH}_{4}\right)$ and climate (as recorded using the Antarctic temperature proxy, the deuterium/ hydrogen ratio in ice, represented as $\delta D$ ) over this period. The Vostok record has become a compelling target against which other records and modelling efforts are tested.

The European Project for Ice Coring in Antarctica (EPICA) is a consortium of laboratories and Antarctic logistics operators from ten nations, with the goal of obtaining two deep ice cores in East Antarctica. The study of one core, from Kohnen Station in the Dronning Maud Land sector of Antarctica (see Supplementary Fig. 1) is aimed at producing a high-resolution record of at least one glacial-interglacial cycle in the sector of Antarctica facing the Atlantic Ocean, for comparison with Greenland records ${ }^{7}$. The second core (named EDC) from Dome C $\left(75^{\circ} 06^{\prime} \mathrm{S}, 123^{\circ} 21^{\prime} \mathrm{E}\right.$, altitude 3,233 $\mathrm{m}$ above sea level), discussed here, is aimed at producing a record of the longest time period possible. The site ${ }^{8}$ has an ice thickness of $3,309 \pm 22 \mathrm{~m}$; the current drilling depth is $3,190 \mathrm{~m}$, of which $3,139 \mathrm{~m}$ has been analysed for a wide range of constituents. The current mean annual surface temperature is $-54.5^{\circ} \mathrm{C}$, and the snow accumulation rate is $25 \mathrm{~kg} \mathrm{~m}^{-2} \mathrm{yr}^{-1}$ $(2.5 \mathrm{~cm}$ water equivalent per year). The drill site is $56 \mathrm{~km}$ from the site of a previous Dome $\mathrm{C}$ core ${ }^{9}$ that provided records extending into the last glacial period, and $560 \mathrm{~km}$ from the site of the Vostok cores $^{1}$. The completion of the Dome $\mathrm{C}$ core was delayed when the first drilling became stuck at $788 \mathrm{~m}$ in 1999, and this shorter EDC96 core has already yielded many important results from the last $45 \mathrm{kyr}$ (see, for example, refs 10-14).

Here we present the EDC records of $\delta D$ and other parameters, analysed at low resolution, for the available core. We show that the core represents $740 \mathrm{kyr}$, including all of marine isotope stage (MIS) 11, which was not completed in the Vostok record, and running through a further three complete 100-kyr cycles, to MIS 18.4. We compare the amplitude and frequency structure of the period before MIS 11 with that of the more recent period. We focus in more detail, with new greenhouse-gas and ice-chemical data, on Termination V, from MIS 12 to MIS 11, discussing first the integrity of the record. The different parameters measured on this termination are then discussed in terms of similarities to and differences from younger terminations.

\section{Stratigraphy of the EDC core}

The ice-core data (see Methods) are reported in Fig. 1 as a function of depth. In this section, conductivity, grain size, dust and $\delta D$ data, taken together, allow us to define a reliable stratigraphy of the core in terms of terminations and of broad correspondence with the deep-sea record. In the following section, we derive a timescalewhich should be considered preliminary-and develop arguments supporting our claim that the core stratigraphy is undisturbed at the current depth $(3,139 \mathrm{~m})$ despite the relative proximity of the bedrock (less than $200 \mathrm{~m}$ ).

Under the conditions at Dome C, both measurements (see Methods) of electrical conductivity ${ }^{15}$ are dominated by variations in the acidity of the ice ${ }^{16}$. This property does not vary in a simple way with climate, increasing in both very cold and very warm stages, 
with the lowest values in intermediate climates. Cold periods in Antarctica are characterized by much greater dust fallout than is found during interglacials (for example, the Last Glacial Maximum (LGM)/Holocene ratio of 26 for dust flux ${ }^{13}$ ), related to a combination of increased aridity and wind strength. Large numbers of dust particles within the ice lead to a decrease in the ice-grain growth rate $^{17}$. Consequently, each significant decrease of the average grain radius (Fig. 1) also marks an interglacial to glacial transition. The isotopic composition of the ice, $\delta D$ (used here) and $\delta^{18} \mathrm{O}$, is classically used as an indicator of temperature change. Isotopic models predict that $\delta$ values should vary linearly with temperature in mid- and high latitudes. There is now a series of arguments supporting the use of this present-day temperature/isotope spatial slope to interpret isotopic records from Antarctica ${ }^{18,19}$, at least for deep ice cores from the East Antarctic plateau.

Electrical, dust and $\delta D$ (Fig. 2) data can easily be matched between the EDC and Vostok cores into stage 11. We deduce that ice from 3,310 $\mathrm{m}$ at Vostok and from $\sim 2,770 \mathrm{~m}$ at EDC corresponds to the same time period ( $423 \mathrm{kyr}$ BP in the GT4 Vostok chronology). Transition $\mathrm{V}$ is then very clearly marked both in the dust, grain size and $\delta D$ records with the coldest part of MIS 12 at around $\sim 2,790 \mathrm{~m}$ (Fig. 1), and with Termination V (that is, the MIS 12 to MIS 11 transition) roughly corresponding to the depth interval between 2,790 and $2,760 \mathrm{~m}$.

Below the dielectric-profiling peak corresponding to MIS 11 there is a large depth interval with low dielectric-profiling values. There is, however, a clear dust peak, as well as a large decrease in the average grain size, at a depth of 2,910 m, which should correspond to the cold MIS 14, thus implying that there is no dielectric-profiling peak within MIS 13. The $\delta D$ record confirms that the interglacial MIS 13 peaks at a depth of $2,842 \mathrm{~m}$, but is considerably colder than subsequent interglacials. This intermediate climate is insufficient to give a dielectric-profiling peak, probably because of reduced preservation of volatile acids ${ }^{20}$.

From the $\delta D$ record, we first note a clear change in the amplitude of glacial-interglacial changes before and after MIS 12, with the
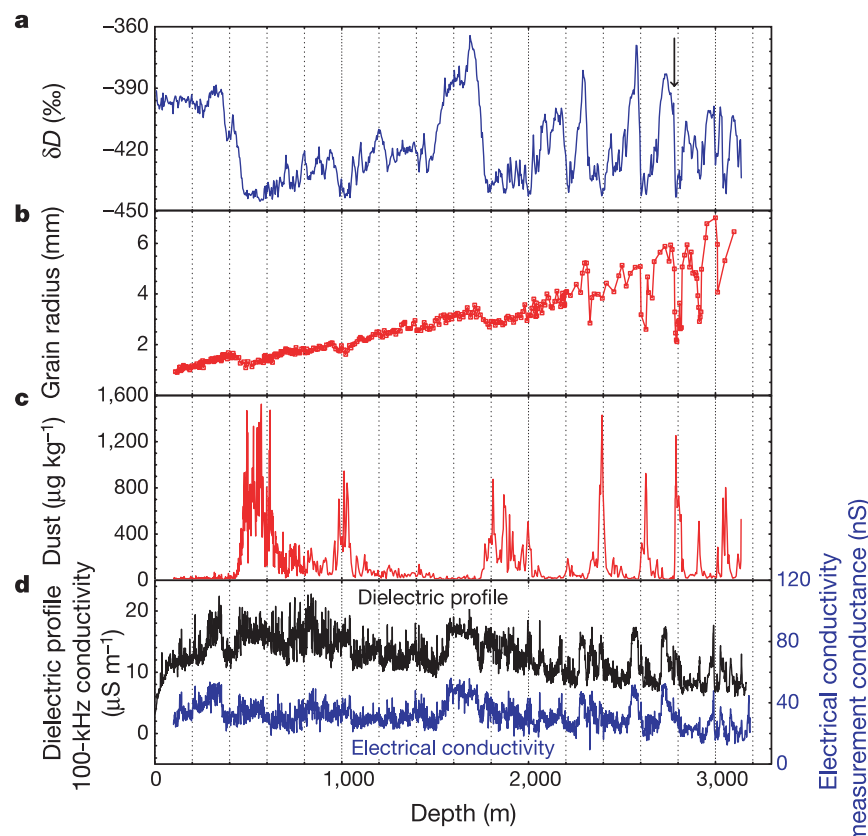

Figure 1 Measured parameters from the EPICA Dome $C$ ice core, on an ice depth scale. a, $\delta D$, averaged over 3.85-m sections. $\mathbf{b}$, Grain radius, measured approximately every $10 \mathrm{~m}$. c. Dust concentration—below $787 \mathrm{~m}$, there is one sample every $5.5 \mathrm{~m}$; above that, one sample every $1.5 \mathrm{~m}$. d, Electrical data (as discussed in the Methods), in 1-m averages. Termination $\mathrm{V}$ is marked by an arrow in $\mathbf{a}$. older period being characterized by just one minimum as deep as those observed during the last $400 \mathrm{kyr}$, and by consistently lower maxima (by about 20\%o). As discussed below, this change of amplitude corresponds to the mid-Brunhes climate shift (and does not result from some smoothing process in the ice). There is an excellent correspondence between the $\delta D$ and the dust record and based on these we can assign the base of the transition at $\sim 3,042 \mathrm{~m}$ to the next cold stage, MIS 16.2. In the deep-sea core record, stage 16.2 corresponds to particularly low sea level and was probably very cold. This is exactly what is seen in the $\delta D$ where, before MIS 12 , only stage 16 reached $\delta D$ levels as low as those of the LGM. The next $\delta D$ peaks (low dust) can then be attributed to full interglacial 17 and interstadial 18.3 with the bottom of the record corresponding to MIS 18.4.

\section{Timescale and integrity of the deep ice}

The timescale (called EDC2; see Methods) developed for the Dome $\mathrm{C}$ deep ice core is based on an inverse dating method ${ }^{21}$, constrained by a small number of control age windows, which are mainly set to glacial terminations by comparison to the marine records. The fact that a simple one-dimensional model with only four free parameters can be matched (to 3,139 m depth) so well, in both timing and shape, with the orbitally tuned marine records (Fig. 2c) is evidence for the integrity of the stratigraphy of the Dome $\mathrm{C}$ record. The good match extends through the period from 338 to $626 \mathrm{kyr}$, in which there are no imposed control windows. The difference between the ages of gas bubbles and the surrounding ice was computed with a firn model ${ }^{22}$.

The first section of EDC ice that is novel, that is, older than was

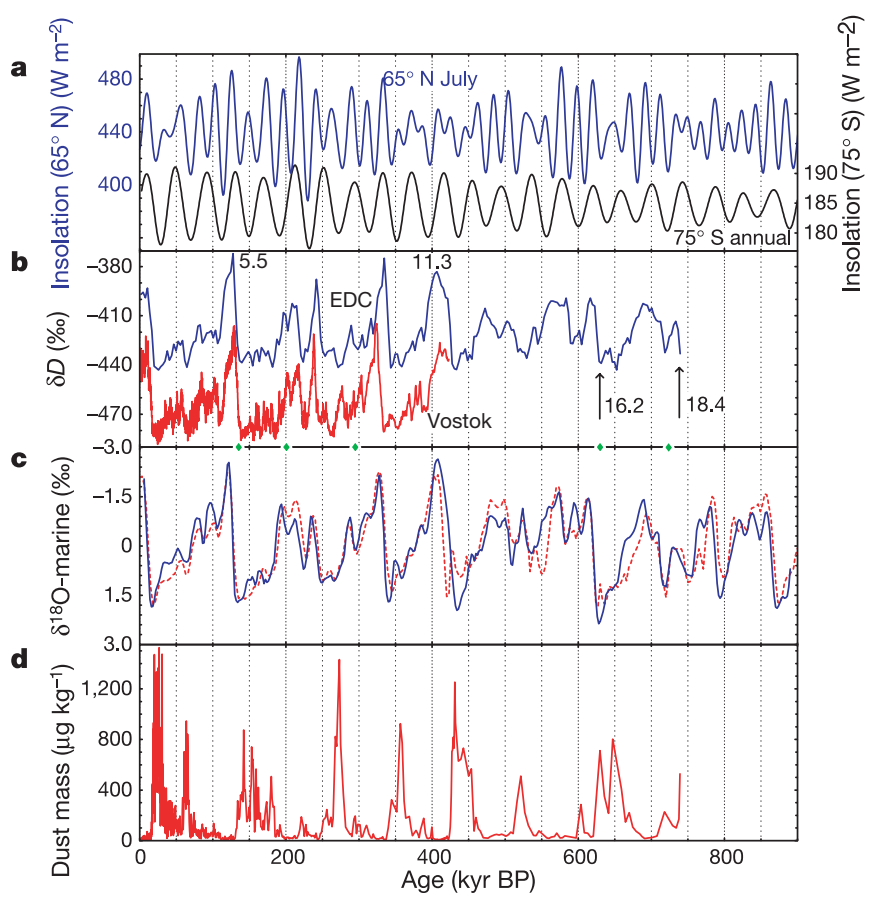

Figure 2 Comparison of EPICA Dome $\mathrm{C}$ data with other palaeoclimatic records. a, Insolation records ${ }^{4}$. Upper blue curve (left axis), mid-July insolation at $65^{\circ} \mathrm{N}$; lower black curve (right axis), annual mean insolation at $75^{\circ} \mathrm{S}$, the latitude of Dome $\mathrm{C} . \mathbf{b}, \delta D$ from EPICA Dome $C\left(3,000\right.$-yr averages). Vostok $\delta D$ (red) is shown for comparison ${ }^{1}$ and some MIS stage numbers are indicated; the locations of the control windows (below 800-m depth) used to make the timescale are shown as diamonds on the $x$ axis. c, Marine oxygen isotope record. The solid blue line is the tuned low-latitude stack of site MD900963 and ODP6773; to indicate the uncertainties in the marine records we also show (dashed red line) another record, which is a stack of seven sites for the last $400 \mathrm{kyr}$ but consisting only of ODP site 677 for the earlier period ${ }^{2}$. Both records have been normalized to their long-term average. d, Dust from EPICA Dome C. 
obtained at Vostok, is that of Termination V. The integrity of this section can be tested using the depth difference expected between contemporaneous events recorded in the gas and the solid phase. We measured $\mathrm{CO}_{2}$ and $\mathrm{CH}_{4}$ mixing ratios in the air enclosed in the ice at $\sim 1-\mathrm{m}$ resolution between 2,760 and 2,800 $\mathrm{m}$ (Fig. 3). From the Vostok findings over the last four terminations ${ }^{23}$, we expect the following pairs of events to be roughly synchronous: (1) the $\mathrm{CO}_{2}$ peak $/ \delta D$ peak, (2) the start of $\mathrm{CO}_{2}$ increase/start of $\delta D$ increase. The depth offset ( $\Delta$ depth) values for these two pairs of 5 to $7 \mathrm{~m}$ are in reasonable agreement with $\Delta$ depth values calculated with the firn densification model, taking into account the thinning function obtained with the ice-flow model (Fig. 3). These observations support the conclusion that this part of the Dome $\mathrm{C}$ record is undisturbed, that is, that there is no folding of the ice.

Although visible ash layers tilted by a few degrees from the horizontal have been observed in the deeper ice, so far we have observed none of the highly inclined layers and overturned folds that were associated with stratigraphic disturbance in the lowest $10 \%$ of the deep Greenland (Summit) ice cores. The electrical records to $3,190 \mathrm{~m}$ also show no unexpectedly rapid changes, of the kind that might be diagnostic of folding. In conclusion, all the evidence supports the integrity of the ice-core stratigraphy to $3139 \mathrm{~m}$.

\section{Antarctic climate beyond MIS 11}

One of the paradoxes of Quaternary climate is the dominance of 100 -kyr periodicity in the past few climatic cycles, even though the amplitude of insolation changes at this period is rather small. This

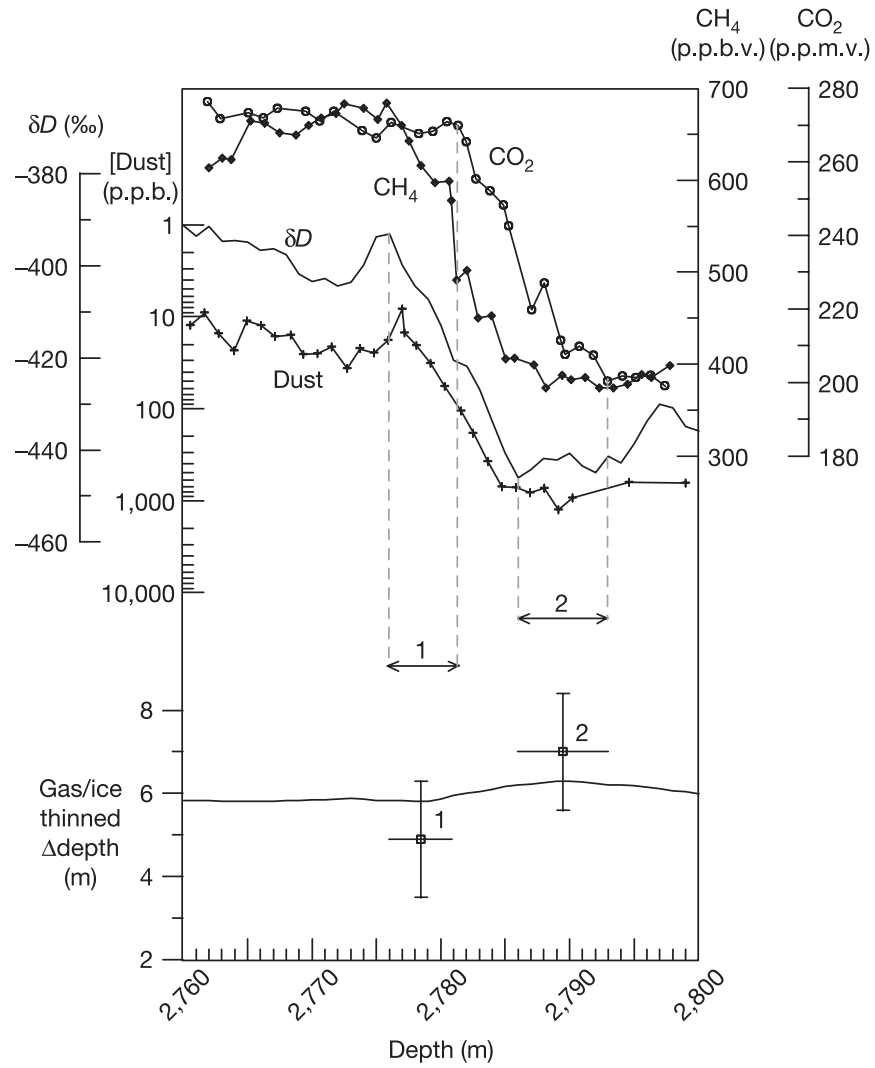

Figure 3 Termination $\mathrm{V}$ in the EPICA Dome $\mathrm{C}$ ice core on an ice depth scale. The top panel shows the ice-core parameters: circles, $\mathrm{CO}_{2}$; diamonds, $\mathrm{CH}_{4}$; line with no symbols, $\delta D$; crosses, dust. The lower panel shows the modelled difference in depth between ice and air of the same age (line) along with estimates of the actual difference (error bars are based on uncertainty in aligning common events) for events considered roughly contemporaneous on the basis of their behaviour in later terminations at Vostok. Event 1 , $\mathrm{CO}_{2}$ peak $\delta \delta$ peak; event $2, \mathrm{CO}_{2}$ early increase $/ \delta D$ early increase. can be addressed by examining changes in the amplitude and frequency of climate through the Quaternary period. On the basis mainly of ice-volume records, two major transitions have been identified. The mid-Pleistocene revolution (MPR) is characterized by an increase in mean global ice volume, and a change in the dominant period from 41 to $100 \mathrm{kyr}$ (ref. 2). Its timing is often considered to be at about $900 \mathrm{kyr}$ BP (that is, before the scope of this paper). A second distinct climate change, the mid-Brunhes event (MBE, for example ${ }^{24}$ ), roughly corresponds to the transition between stage 12 and stage 11 (Termination V) about $430 \mathrm{kyr}$ ago. The MBE is characterized by a further increase of ice-volume variations with, from then to the present day, four large-amplitude 100-kyr-dominated glacial-interglacial cycles. The intermediate period between the MPR and the MBE is characterized by a lessclear pattern. This schematic description of Quaternary climate, largely based on deep-sea isotopic records of ice-volume changes, also holds for at least some sea surface temperature records. For example, a composite South Atlantic 1,830-kyr record ${ }^{25}$ shows cold and relatively stable summer temperatures before the MPR followed by higher-amplitude fluctuations between the MPR and the MBE and much stronger variations thereafter. Now we have the opportunity to examine the pre-MBE signal in Antarctic temperature and dust.

In the $\mathrm{EDC} \delta D$ record (Fig. 2), as in the marine-isotope records, the most striking feature is the greater amplitude of glacial-interglacial change in the period after Termination V (with $430 \mathrm{kyr}$ as the boundary), compared to the earlier period. The standard deviation of the signals increases by $45 \%$ for EDC and $12 \%$ for the $\delta^{18} \mathrm{O}$ record of ref. 3; other planktonic series show a similar feature ${ }^{24}$. The Devil's Hole calcite isotopic record ${ }^{26}$, which, however, extends only back to $565 \mathrm{kyr}$ BP, also shows less variability before than after the MBE and indeed resembles the EDC record over the part common to both records. In detail, the period before Termination $\mathrm{V}$ in EDC is characterized by somewhat less cold glacial maxima (with the exception of stage 16.2), but by very significantly less warm interglacials (Fig. 4). Less extreme (weaker amplitude) interglacials occupied a larger proportion of each glacial/interglacial cycle, with the result that the mean $\delta D$ value before and after $430 \mathrm{kyr}$ is quite similar. The new ice-core data strongly emphasize the contrast in climate before and after the MBE.

The driving mechanisms for neither the MPR nor the MBE are as yet well understood. Some properties of the insolation curves have

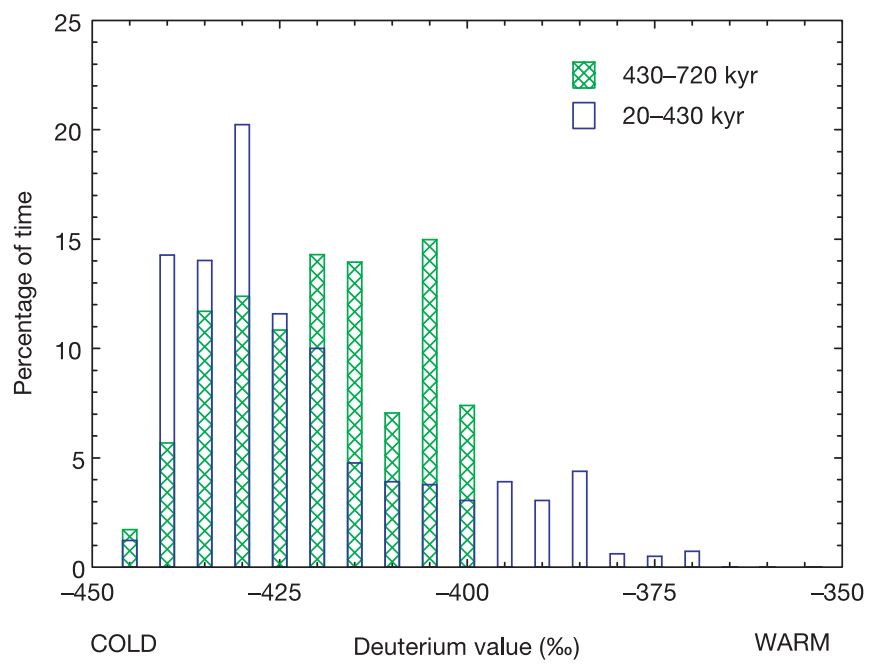

Figure 4 Histogram of $\delta D$ values before and after $430 \mathrm{kyr}$. The bars show the occurrence of values within $5 \%$ windows for each of the periods, indicating that for the earlier period, there are no very warm values, but the time spent in warm and cold periods is more even than in the later period. 


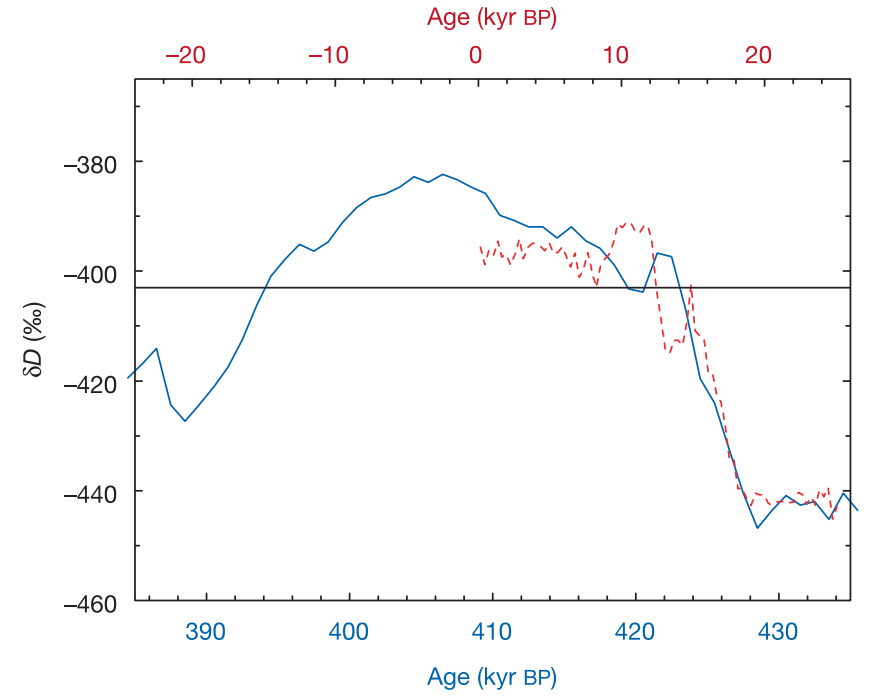

Figure 5 Comparison of Termination V plus MIS 11 with Termination I plus Holocene. $\delta D$ data for MIS 11 (1-kyr averages) are shown as a solid blue line using the lower $x$ axis; data for the Holocene are shown as a dashed red line using the upper $x$ axis. Various alignments could be made, but we have adjusted the $x$ axes so that the start of each termination is aligned. A horizontal line is drawn at $-403 \%$.

changed progressively over the last $800 \mathrm{kyr}$, with an increased amplitude of obliquity changes, for example, and therefore an increased variability of annual local insolation (Fig. 2a) in the later part of the record. However, none of the simple conceptual models developed to simulate the timing of the Pleistocene glaciations has been able to suggest an explanation of the MBE. The climate became more orderly and predictable after the MBE, perhaps as a result of the emergence of new feedback mechanisms linked with changes in boundary conditions, such as the strength of ocean circulation, albedo, carbon dioxide or isostasy ${ }^{24}$. At this stage, we have no additional clues allowing us to favour any one of these feedbacks, or to formulate other possibilities, but to obtain a detailed carbon dioxide record over 800,000 yr should certainly be helpful.

A final issue concerning the complete record is the stability in the size of the Antarctic ice sheet. Preliminary measurements of air content made between 2762.1 and $2783.0 \mathrm{~m}$ depth (MIS 11), between 3054.7 and $3059.1 \mathrm{~m}$ (MIS 16.3) and between 3099.8 and $3100.9 \mathrm{~m}$ (MIS 17.3) show the same mean value as that of EDC ice dating from the last $40 \mathrm{kyr}\left(0.089 \mathrm{~cm}^{3} \mathrm{~g}^{-1}\right)$. This suggests ${ }^{27}$ that over the last $700 \mathrm{kyr}$, the surface elevation in this central part of East Antarctica has been as stable as during the last $40 \mathrm{kyr}$. This sets constraints, probably of the order of $5 \mathrm{~m}$ (ref. 28), on the possible contribution of this part of East Antarctica to changes in sea level ${ }^{29}$.

\section{Termination V}

MIS 11 emerges as a key interglacial, both as viewed from the atmosphere in the EDC record and from the ocean in the $\delta^{18} \mathrm{O}$ marine records. It delimits the frontier between two different patterns of climate, and has been identified as a unique and exceptionally long interglacial ${ }^{30}$. Some authors suggest that, because the orbital parameters (low eccentricity and consequently weak precessional forcing) are similar to those of the present and the next tens of thousands of years, MIS 11 may be the best analogue for present and future climate without human intervention ${ }^{31}$. In this context, we note (Fig. 5) that, on the EDC2 timescale, $\delta D$ (our temperature proxy) remains above $-403 \%$ o (the minimum $300-y r$ average value observed during the full Holocene epoch) for $28 \mathrm{kyr}$ in MIS 11 (apart from a brief reversal near the start); in the Holocene, $\delta D$ has so far been above $-403 \%$ o for $12 \mathrm{kyr}$. The rate of change in $\delta D$ is very similar in Terminations V and I. Both terminations show a clear temperature reversal, but the one in the earlier period occurs after interglacial warmth has already been achieved. Thus the reversal at about $420 \mathrm{kyr}$ might be seen as analogous to the Antarctic cold reversal (ACR) that occurred during Termination I at around $13 \mathrm{kyr}$, or it might be seen as similar to the dip (at about $8 \mathrm{kyr}$ ) that occurred after the early Holocene warm period.

Our low-resoluion data for $\mathrm{CO}_{2}, \mathrm{CH}_{4}$ (Fig. 3) and other parameters already provide information on how Termination $\mathrm{V}$ mimics or differs from younger terminations in terms of coupling between climate and greenhouse gases. With a minimum at 200 p.p.m.v. and 380 p.p.b.v. at the end of MIS 12 and a maximum at 275 p.p.m.v. and 680 p.p.b.v. at the start of MIS $11, \mathrm{CO}_{2}$ and $\mathrm{CH}_{4}$ mixing ratios lie within the range observed during younger glacials and interglacials ${ }^{1}$, the MIS 12 values being slightly at the higher end of the glacial range. These observations and the incomplete MIS $11 \mathrm{CO}_{2}$ record measured along the Vostok ice core ${ }^{28}$ rule out unusual greenhouse conditions during MIS $11^{32}$ or a link between coral-reef growth and the intense carbonate dissolution of MIS 11 through unusual $\mathrm{CO}_{2}$ mixing $\operatorname{ratios}^{30}$. Other parameters measured on the core (Table 1), representing conditions and transport in different compartments of the environment, have very similar (glacial) values at equivalent points just before Terminations I and V and very similar (interglacial) values just after the two transitions. This confirms that, in all the proxies we are able to examine, there is no significant long-term trend in the period since the MBE.

The general shape of the greenhouse gas increases resembles younger terminations, that is, a regular trend for $\mathrm{CO}_{2}$ and a twostep transition for $\mathrm{CH}_{4}$ (slow increase followed by a rapid jump towards interglacial values); however, no Younger-Dryas-like event is observed in our $\mathrm{CH}_{4}$ profile.

The most striking feature concerns the relative timing of the $\mathrm{CO}_{2}$ and $\mathrm{CH}_{4}$ increases compared with younger terminations: whereas $\mathrm{CH}_{4}$ started to increase concomitantly with $\mathrm{CO}_{2}$ (and Antarctic temperature) during the last four terminations, at Termination $\mathrm{V}$ it leaves its glacial background 4 to $5 \mathrm{kyr}$ later than $\mathrm{CO}_{2}$, by which time the latter had already increased by about 50 p.p.m.v. Similarly, the rapid jump of $\mathrm{CH}_{4}$ punctuating the second part of its transition takes place when $\mathrm{CO}_{2}$ approaches its maximum. Note that this is also the time when Antarctic temperature starts a slow decrease, that is, a typical expression of a bipolar see-saw as observed during stage 3 (ref. 33) and possibly Termination $\mathrm{I}^{12}$. Following its rapid jump at

\begin{tabular}{|c|c|c|c|c|}
\hline Analytes & $\begin{array}{c}6-8 \mathrm{kyr} \text { BP } \\
\text { (after Termination I) }\end{array}$ & $\begin{array}{c}20-22 \text { kyr BP } \\
\text { (before Termination I) }\end{array}$ & $\begin{array}{c}\text { 416-418 kyr BP } \\
\text { (after Termination V) }\end{array}$ & $\begin{array}{c}\text { 430-432 kyr BP } \\
\text { (before Termination V) }\end{array}$ \\
\hline$\delta D(\%)$ & -399 & -442 & -395 & -442 \\
\hline $\mathrm{CO}_{2}$ (p.p.m.v.) & 260 & 185 & 270 & 200 \\
\hline $\mathrm{CH}_{4}$ (p.p.b.v.) & 600 & 360 & 670 & 390 \\
\hline Dust $\left(\mu \mathrm{g} \mathrm{kg}^{-1}\right)$ & 14 & 680 & 24 & 630 \\
\hline $\mathrm{Na}\left(\mu \mathrm{g} \mathrm{kg}^{-1}\right)$ & 20 & 101 & 23 & 99 \\
\hline $\mathrm{SO}_{4}^{2-}\left(\mu \mathrm{g} \mathrm{kg}^{-1}\right)$ & 92 & 201 & 98 & 216 \\
\hline
\end{tabular}

Gas values are for Dome C. No corrections for interhemispheric differences or global averages have been applied. Data is shown for approximately equivalent periods before and after Terminations I and $\mathrm{V}$. 
the end of the termination, $\mathrm{CH}_{4}$ continues to increase by $\sim 100$ p.p.b.v. for 2 to $3 \mathrm{kyr}$, another unusual feature when compared to the $\mathrm{CH}_{4}$ trends during the early part of MIS 1, 5, 7 and 9 (ref. 1).

A thorough discussion of the causes of these greenhouse-gas peculiarities during Termination $\mathrm{V}$ is beyond the scope of this paper. But evidently the similarities and differences observed with younger terminations will stimulate the debate on how greenhouse gas and climate are coupled on Quaternary timescales.

\section{Prospects from the rest of the core}

In this paper, we have shown the extended climate record back to $740 \mathrm{kyr}$, and that the pattern of climate before MIS 11 was different to that which has followed for the past four glacial cycles. Although the results from MIS 11 indicate that without human intervention a climate similar to the present one would extend well into the future, the predicted increases in greenhouse-gas concentrations make this unlikely $^{34}$.

According to our preliminary timescale, extending the record to 3,190 $\mathrm{m}$ (ice already drilled but not analysed) will take the record back to $807 \pm 10 \mathrm{kyr}$ (MIS 20.2). The electrical records already obtained on this ice (Fig. 1), although difficult to interpret simply in terms of climate, certainly suggest that another glacial cycle will be found in this ice. This ice should include the Brunhes-Matuyama magnetic reversal, generally dated to about $780 \mathrm{kyr}$, and therefore give us the first indication of how a reversal is recorded in cosmogenic isotopes such as ${ }^{10} \mathrm{Be}$.

There remains up to $120 \mathrm{~m}$ of ice still to drill. This will be difficult to obtain because the ice is near to the melting temperature. The timescale EDC2 extended to the base gives an age of $960 \pm 20 \mathrm{kyr}$. Therefore, when the record is complete, we could expect to reach MIS 26 (just beyond the MPR), assuming that the integrity of the stratigraphy and all the approximations of the dating method are still reasonable down to the base. It will be of particular interest to see how the tight coupling between greenhouse gases and Antarctic temperature $(\delta D)$ seen in the last 420 kyr evolves through the earlier parts of the record.

\section{Methods}

\section{Analysis}

The electrical conductivity measurement determines the d.c. conductance between electrodes on a fresh ice surface. Dielectric profiling determines the conductivity of the ice at higher frequencies. Both were measured in the field at a temperature of $-20 \pm 2{ }^{\circ} \mathrm{C}$, corrected ${ }^{15,16}$ to $-15^{\circ} \mathrm{C}$. Data were collected at high resolution and averaged to $1 \mathrm{~m}$. Vertical thin sections were prepared in the field at a periodicity of $10 \mathrm{~m}$, then digitized and analysed using an image analysis procedure ${ }^{35}$ to determine the mean grain radius. A $3.4 \mathrm{~cm} \times 3.4 \mathrm{~cm}$ strip of ice was melted on a hotplate in the field ${ }^{36}$, and fed into various detectors. Aliquots (1.1-m averages) were also collected from this melting device into clean containers, frozen and shipped to Europe for ion chromatographic analysis ${ }^{37}$ of major ions (presented for Termination V). All other measurements were made in laboratories in Europe after the ice had been shipped frozen from Dome C. $\delta D$ was determined ${ }^{10}$ on meltwater from 55-cm-long sections. This record, still discontinuous for some parts, should be considered as preliminary. Also, we used a 'quick' mode (each sample is measured twice instead of four times), leading to a typical accuracy of $1.5 \%$ o $(1 \sigma)$, whereas we aim for a final precision of $0.5 \%$ over the entire core, as currently obtained for EDC96 (the upper $780 \mathrm{~m}$ ). $\delta D$ data shown in Fig. 1 correspond to values averaged across seven successive samples. The current precision and resolution are well adapted for the climatic interpretation discussed here (Fig. 2), in which we focus on the broad features of Antarctic climate changes over the past eight climatic cycles.

Dust concentration and size distribution was measured by a 256-channel Coulter Counter, set to register particles in the size range from $0.7-20 \mu \mathrm{m}$ (ref. 13). In calculating mass concentrations, density was taken as $2,500 \mathrm{~kg} \mathrm{~m}^{-3} \cdot \mathrm{CO}_{2}$ and $\mathrm{CH}_{4}$ were measured (for Termination V) by a dry crushing ${ }^{12}$ and a melt-refreezing extraction technique ${ }^{38}$, respectively.

\section{Models used for ice-core dating}

Full details of the derivation of the timescale are given in the Supplementary Information. For the thinning rate computation, we used an ice-flow model ${ }^{39}$, with prescribed surface elevation ${ }^{40}$. It has two poorly known parameters: the melting at the base of the ice sheet $(F)$, which is the condition for the vertical velocity at the base, and a parameter $(\mathrm{m})$ for the vertical velocity profile. The vertical strain rate is assumed to be proportional to $1-(z / H)^{(m+1)}$, where $z$ is the depth and $H$ is the ice thickness. The accumulation rate is deduced from the $\delta D$ content of the ice, via the temperature of the inversion layer. This conversion involves two further tunable parameters. The last modelling step of the chronology is the evaluation of the difference between the gas age and the ice age ( $\Delta$ age), which is required to derive the age scale for the gas measurements. This is derived from a firn model $^{22}$. The four poorly known parameters of the models are evaluated through the use of a small number of chronological controls, through a Monte Carlo inverse method $^{5,21}$. The method searches for an optimal agreement, within the limits of the confidence interval of each assigned age (that is, we use control windows rather than control points) and using the same rules to define accumulation all along the record. In the top part of the core, we use the same control points as were used to derive the timescale (EDC1) recommended for the shallower part of the core ${ }^{41}$; EDC1 remains the recommended timescale for this part of the core, and hands over precisely to EDC2 at $800 \mathrm{~m}$. For the bottom part of the core (that is, for the period older than $50 \mathrm{kyr}$ ), we used several age control windows derived by comparison to the stacked marine isotope curve of Bassinot $^{3}$, assuming a 4 -kyr phase lag. These points are situated at Terminations II $(1,738 \mathrm{~m}=131 \pm 6 \mathrm{kyr})$, III $(2,311 \mathrm{~m}=245 \pm 6 \mathrm{kyr})$, IV $(2,593 \mathrm{~m}=338 \pm 6 \mathrm{kyr})$, VII $(3,038 \mathrm{~m}=626 \pm 6 \mathrm{kyr})$ and VIII $(3,119 \mathrm{~m}=717 \pm 6 \mathrm{kyr})$. Note that the age of identical events in this EDC2 chronology can differ, over their common parts, from the Vostok and Dome Fuji chronologies, because of slightly different best-fit parameters in the model.

Received 27 February; accepted 22 April 2004; doi:10.1038/nature02599.

1. Petit, J. R. et al. Climate and atmospheric history of the past 420,000 years from the Vostok ice core, Antarctica. Nature 399, 429-436 (1999)

2. Imbrie, J. et al. On the structure and origin of major glaciation cycles. 2. The 100,000-year cycle. Paleoceanography 8, 699-735 (1993).

3. Bassinot, F. C. et al. The astronomical theory of climate and the age of the Brunhes-Matuyama magnetic reversal. Earth Planet. Sci. Lett. 126, 91-108 (1994).

4. Berger, A. \& Loutre, M. F. Insolation values for the climate of the last 10 million years. Quat. Sci. Rev. 10, 297-317 (1991).

5. Watanabe, O. et al. Homogeneous climate variability across East Antarctica over the past three glacial cycles. Nature 422, 509-512 (2003).

6. Fischer, H., Wahlen, M., Smith, J., Mastroianni, D. \& Deck, B. Ice core records of atmospheric $\mathrm{CO}_{2}$ around the last three glacial terminations. Science 283, 1712-1714 (1999).

7. Johnsen, S. J. et al. Oxygen isotope and palaeotemperature records from six Greenland ice-core stations: Camp Century, Dye-3, GRIP, GISP2, Renland and NorthGRIP. J. Quat. Sci. 16, 299-307 (2001).

8. The EPICA Dome C 2001-02 science and drilling teams, Extending the ice core record beyond half a million years. Eos Trans. 83, 509-517 (2002).

9. Lorius, C., Merlivat, L., Jouzel, J. \& Pourchet, M. A 30,000-yr isotope climatic record from Antarctic ice. Nature 280, 644-648 (1979).

10. Jouzel, J. et al. A new 27 ky high resolution East Antarctic climate record. Geophys. Res. Lett. 28, 3199-3202 (2001).

11. Stenni, B. et al. An oceanic cold reversal during the last deglaciation. Science 293, 2074-2077 (2001).

12. Monnin, E. et al. Atmospheric $\mathrm{CO}_{2}$ concentrations over the last glacial termination. Science 291, 112-114 (2001).

13. Delmonte, B., Petit, J. R. \& Maggi, V. Glacial to Holocene implications of the new 27000 -year dust record from the EPICA Dome C (East Antarctica) ice core. Clim. Dyn. 18, 647-660 (2002).

14. Röthlisberger, R. et al. Dust and sea salt variability in central East Antarctica (Dome C) over the last 45 kyrs and its implications for southern high-latitude climate. Geophys. Res. Lett. 29, doi:10.1029/ 2002GL015186 (2002)

15. Stauffer, B., Flückiger, J., Wolff, E. W. \& Barnes, P. R. F. The EPICA deep ice cores: First results and perspectives. Ann. Glaciol. (in the press).

16. Wolff, E. W., Basile, I., Petit, J.-R. \& Schwander, J. Comparison of Holocene electrical records from Dome C and Vostok, Antarctica. Ann. Glaciol. 29, 89-93 (1999).

17. Weiss, J. et al. Dome Concordia ice microstructure: impurities effect on grain growth. Ann. Glaciol. 35, $552-558$ (2002).

18. Jouzel, J. et al. Magnitude of isotope/temperature scaling for interpretation of central Antarctic ice cores. J. Geophys. Res. 108, doi:10.1029/2002JD002677 (2003).

19. Blunier, T., Schwander, J., Chappellaz, J., Parrenin, F. \& Barnola, J. M. What was the surface temperature in central Antarctica during the last glacial maximum? Earth Planet. Sci. Lett. 218, 379-388 (2004).

20. Röthlisberger, R. et al. Limited dechlorination of sea salt aerosols during the last glacial periodEvidence from the European Project for Ice Coring in Antarctica (EPICA) Dome C ice core. J. Geophys. Res. 108, doi:10.1029/2003JD003604 (2003).

21. Parrenin, F., Jouzel, J., Waelbroeck, C., Ritz, C. \& Barnola, J. M. Dating the Vostok ice core by an inverse method. J. Geophys. Res. 106, 31837-31851 (2001).

22. Goujon, C., Barnola, J. M. \& Ritz, C. Modeling the densification of polar firn including heat diffusion: Application to close-off characteristics and gas isotopic fractionation for Antarctica and Greenland sites. J. Geophys. Res. 108, doi:10.1029/2002JD003319 (2003).

23. Pepin, L., Raynaud, D., Barnola, J. M. \& Loutre, M. F. Hemispheric roles of climate forcings during glacial-interglacial transitions as deduced from the Vostok record and LLN-2D model experiments. J. Geophys. Res. 106, 31885-31892 (2001).

24. Berger, W. H. \& Wefer, G. in Earth's Climate and Orbital Eccentricity: the Marine Isotope Stage 11 Question Geophys. Monogr 137 (eds Droxler, A. W., Poore, R. Z. \& Burckle, L. H.) 41-59 (AGU, Washington, 2003).

25. Becquey, S. \& Gersonde, R. Past hydrographic and climatic changes in the Subantarctic Zone of the South Atlantic-The Pleistocene record from ODP Site 1090. Palaeogeogr. Palaeoclimatol. Palaeoecol. 182, 221-239 (2002).

26. Winograd, I. J. et al. Continuous 500,000-year climate record from vein calcite in Devils-Hole, Nevada. Science 258, 255-260 (1992).

27. Martinerie, P., Raynaud, D., Etheridge, D. M., Barnola, J.-M. \& Mazaudier, D. Physical and climatic parameters which influence the air content in polar ice. Earth Planet. Sci. Lett. 112, 1-13 (1992).

28. Raynaud, D., et al. in Earth's Climate and Orbital Eccentricity: the Marine Isotope Stage 11 Question Geophys. Monogr. 137 (eds Droxler, A. W., Poore, R. Z. \& Burckle, L. H.) 27-40 (AGU, Washington, 2003).

29. Hearty, P. J., Kindler, P., Cheng, H. \& Edwards, R. L. A +20 m middle Pleistocene sea-level highstand 
(Bermuda and the Bahamas) due to partial collapse of Antarctic ice. Geology 27, 375-378 (1999).

30. Droxler, A. W., Alley, R. B., Howard, W. R., Poore, R. Z. \& Burckle, L. H. in Earth's Climate and Orbita Eccentricity: the Marine Isotope Stage 11 Question Geophys. Monogr. 137 (eds Droxler, A. W., Poore, R. Z. \& Burckle, L. H.) 1-14 (AGU, Washington, 2003).

31. Berger, A. \& Loutre, M. F. in Earth's Climate and Orbital Eccentricity: the Marine Isotope Stage 11 Question Geophys. Monogr. 137 (eds Droxler, A. W., Poore, R. Z. \& Burckle, L. H.) 17-26 (AGU, Washington, 2003).

32. Lea, D. W., Pak, D. K. \& Spero, H. J. in Earth's Climate and Orbital Eccentricity: the Marine Isotope Stage 11 Question Geophys. Monogr. 137 (eds Droxler, A. W., Poore, R. Z. \& Burckle, L. H.) 147-156 (AGU, Washington, 2003).

33. Stocker, T. F. \& Johnsen, S. J. A minimum thermodynamic model for the bipolar seesaw. Paleoceanography 18, doi:10.1029/2003PA000920 (2003).

34. IPCC, IPCC Third Assessment Report: Climate Change 2001: The Scientific Basis (Cambridge Univ. Press, Cambridge, 2001).

35. Gay, M. \& Weiss, J. Automatic reconstruction of polycrystalline ice microstructure from image analysis: application to the EPICA ice core at Dome Concordia, Antarctica. J. Glaciol. 45, 547-554 (1999).

36. Röthlisberger, R. et al. Technique for continuous high-resolution analysis of trace substances in firn and ice cores. Environ. Sci. Technol. 34, 338-342 (2000).

37. Littot, G. C. et al. Comparison of analytical methods used for measuring major ions in the EPICA Dome C (Antarctica) ice core. Ann. Glaciol. 35, 299-305 (2002).

38. Landais, A. et al. A tentative reconstruction of the last interglacial and glacial inception in Greenland based on new gas measurements in the Greenland Ice Core Project (GRIP) ice core. J. Geophys. Res.
108, doi:10.1029/2002JD003147 (2003)

39. Ritz, C.. Un Modèle Thermo-Méchanique d'Évolution pour le Bassin Glaciaire Antarctique Vostok-Glacier Byrd: Sensibilité aux Valeurs des Paramètres Mal Connus Thesis, Univ. J. Fourier (1992).

40. Ritz, C., Rommelaere, V. \& Dumas, C. Modeling the evolution of Antarctic ice sheet over the last 420,000 years: Implications for altitude changes in the Vostok region. J. Geophys. Res. 106, 31943-31964 (2001).

41. Schwander, J. et al. A tentative chronology for the EPICA Dome Concordia ice core. Geophys. Res. Lett. 28, 4243-4246 (2001).

Supplementary Information accompanies the paper on www.nature.com/nature

Acknowledgements We thank the logistics and drilling teams. This work is a contribution to the European Project for Ice Coring in Antarctica (EPICA), a joint European Science Foundation/ European Commission (EC) scientific programme, funded by the EC and by national contributions from Belgium, Denmark, France, Germany, Italy, The Netherlands, Norway, Sweden, Switzerland and the UK.

Competing interests statement The authors declare that they have no competing financial interests.

Correspondence and requests for materials should be addressed to E.W. (ewwo@bas.ac.uk).

EPICA community members* (participants are listed alphabetically)

Laurent Augustin', Carlo Barbante ${ }^{2}$, Piers R. F. Barnes ${ }^{3}$, Jean Marc Barnola1, Matthias Bigler ${ }^{4}$, Emiliano Castellano ${ }^{5}$, Olivier Cattani' $^{6}$, Jerome Chappellaz', Dorthe Dahl-Jensen ${ }^{7}$, Barbara Delmonte ${ }^{1,8}$, Gabrielle Dreyfus ${ }^{6}$, Gael Durand', Sonia Falourd ${ }^{6}$, Hubertus Fischer ${ }^{9}$, Jacqueline Flückiger ${ }^{4}$, Margareta E. Hansson ${ }^{10}$, Philippe Huybrechts ${ }^{9}$, Gérard Jugie ${ }^{11}$, Sigfus J. Johnsen ${ }^{7}$, Jean Jouzel ${ }^{6}$, Patrik Kaufmann ${ }^{4}$, Josef Kipfstuhl ${ }^{9}$, Fabrice Lambert ${ }^{4}$, Vladimir Y. Lipenkov ${ }^{12}$, Geneviève C. Littot ${ }^{3}$, Antonio Longinelli ${ }^{13}$, Reginald Lorrain ${ }^{14}$, Valter Maggi ${ }^{8}$, Valerie Masson-Delmotte ${ }^{6}$, Heinz Miller ${ }^{9}$, Robert Mulvaney ${ }^{3}$, Johannes Oerlemans ${ }^{15}$, Hans Oerter ${ }^{9}$, Giuseppe Orombelli ${ }^{8}$, Frederic Parrenin ${ }^{1,6}$, David A. Peel ${ }^{3}$, Jean-Robert Petit ${ }^{1}$, Dominique Raynaud ${ }^{1}$, Catherine Ritz ${ }^{1}$, Urs Ruth ${ }^{9}$, Jakob Schwander ${ }^{4}$, Urs Siegenthaler ${ }^{4}$, Roland Souchez ${ }^{14}$, Bernhard Stauffer ${ }^{4}$, Jorgen Peder Steffensen ${ }^{7}$, Barbara Stenni ${ }^{16}$, Thomas F. Stocker ${ }^{4}$, Ignazio E. Tabacco ${ }^{17}$, Roberto Udisti ${ }^{5}$, Roderik S. W. van de Wal ${ }^{15}$, Michiel van den Broeke ${ }^{15}$, Jerome Weiss ${ }^{1}$, Frank Wilhelms ${ }^{9}$, Jan-Gunnar Winther ${ }^{18}$, Eric W. Wolff ${ }^{3}$ \& Mario Zucchelli ${ }^{19 \star}$

1, Laboratoire de Glaciologie et Géophysique de l'Environnement (CNRS), BP 96, 38402 St Martin d'Hères Cedex, France; 2, Environmental Sciences Department, University of Venice, Calle Larga S. Marta, 2137, I-30123 Venice, Italy; 3, British Antarctic Survey, High Cross, Madingley Road, Cambridge CB3 OET, UK; 4, Climate and Environmental Physics, Physics Institute, University of Bern, Sidlerstrasse 5, CH-3012 Bern, Switzerland; 5, Department of Chemistry-Analytical Chemistry Section, Scientific Pole-University of Florence, Via della Lastruccia 3, 50019 Sesto Fiorentino (Florence), Italy; 6, Institut Pierre Simon Laplace/Laboratoire des Sciences du Climat et de l'Environnement, UMR CEA-CNRS 1572, CE Saclay, Orme des Merisiers, 91191 Gif-Sur-Yvette, France; 7, Niels Bohr Institute for Astronomy, Physics and Geophysics, University of Copenhagen, Juliane Maries Vej 30, DK-2100 Copenhagen, Denmark; 8, University of Milano-Bicocca, Dipartimento di Scienze Ambiente e Territorio, Piazza della Scienza 1, I-20126 Milan, Italy; 9, Alfred-Wegener-Institute for Polar- und Marine Research (AWI), Postfach 120161, D-27515 Bremerhaven, Germany; 10, Department of Physical Geography and Quaternary Geology, Stockholm University, S-106 91 Stockholm, Sweden; 11, Institut Polaire Français-Paul Emile Victor (IPEV), BP 75, 29280 Plouzane, France; 12, Arctic and Antarctic Research Institute, 38 Beringa Street, 199397 St Petersburg, Russia; 13, Department of Earth Sciences, University of Parma, Parco Area delle Scienze 157/A, I-43100 Parma, Italy; 14, Département des Sciences de la Terre et de l'Environnement, Faculté des Sciences, CP 160/03, Université Libre de Bruxelles, 50 avenue FD Roosevelt, B1050 Brussels, Belgium; 15, Institute for Marine and Atmospheric Research Utrecht (IMAU), Princetonplein 5, 3584 CC Utrecht, The Netherlands; 16, Department of Geological, Environmental and Marine Sciences, University of Trieste, Via E. Weiss 2, I-34127 Trieste, Italy; 17, Earth Science Department, University of Milan, Via Cicognara 7, 20129 Milano, Italy; 18, Norwegian Polar Institute, N-9296 Tromsø, Norway; 19, ENEA, CRE Casaccia, PO Box 2400, Via Anguillarese 301, 00060 S. Maria di Galleria (RM), Italy.

${ }^{\star}$ Deceased. 